\title{
THE PHYTOCHEMICAL SCREENING HEXANE AND METHANOL EXTRACT OF SINYO NAKAL (DURANTA REPENS)
}

\author{
PURWANTININGSIH SUGITA ${ }^{1 *}$, RIZKI AMILIA ${ }^{1}$, BUDI ARIFIN ${ }^{1}$, DYAH UTAMI CAHYANING RAHAYU², \\ HANHAN DIANHAR
}

${ }^{1}$ Department of Chemistry, Faculty of Mathematics and Natural Sciences, IPB University, Bogor, Indonesia. ${ }^{2}$ Department of Chemistry, Faculty of Mathematics and Natural Sciences, Universitas Indonesia, Depok, Indonesia. ${ }^{3}$ Chemistry Study Program, Faculty of Mathematics and Natural Sciences, Universitas Negeri Jakarta, Jakarta, Indonesia. Email: purwantiningsih@apps.ipb.ac.id

Received: 07 May 2020, Revised and Accepted: 20 June 2020

\section{ABSTRACT}

Objective: Phytochemicals are naturally present in every part of plants range from leaves, stem bark, and fruits to roots. The use of plant-based medicine is popular among individuals and communities in developing countries. This study evaluated that the phytochemical profile of Duranta repens fruits was collected from Jombang, East Java, Indonesia.

Methods: Air-dried D. repens fruits were macerated by $n$-hexane and methanol, a separate flask. $n$-Hexane extract, then underwent saponification to remove fat. Then, the unsaponifiable of $n$-hexane and methanol extract was tested through phytochemical screening, respectively.

Results: The methanol extract showed the presence of alkaloids, flavonoids, tannins, and steroids, but the unsaponifiable fraction only contained steroids. The unsaponifiable fraction was found to be a mixture of hydrocarbons ranging from $\mathrm{C}_{13}-\mathrm{C}_{20}$, fatty acids (palmitic and linoleic acid), squalene, and Vitamin E.

Conclusion: The phytochemical screening of the plant plays an important role for pharmaceutical studies especially discovering new potential drugs for the treatment of various diseases.

Keywords: Duranta repens, Unsaponifiable hexane fraction, Methanol extract.

(C) 2020 The Authors. Published by Innovare Academic Sciences Pvt Ltd. This is an open access article under the CC BY license (http://creativecommons. org/licenses/by/4. 0/) DOI: http://dx.doi.org/10.22159/ajpcr.2020.v13i8.38165

\section{INTRODUCTION}

The use of medicinal plants has become popular among individuals and communities in developing countries. Plants produce various bioactive compounds that contain components of therapeutic value making them a rich source of medicines. Duranta repens Linn. belonging to family Verbenaceae is native to clean and open forests. It is used as an ornamental plant in tropical nations. The local community in Indonesia commonly calls this plant as sinyo nakal (Fig. 1). The plants belong to Verbenaceae family which are herbs, shrubs, or trees comprising about 100 genus and 2600 species [1]. Around 35 Duranta species with evergreen bushes are spread over tropical and subtropical areas. D. repens is also known as Duranta plumieri, Duranta erecta, and Duranta microphylla [2,3].

Different parts of the plant are used to treat a variety of diseases. The fruit and leaves are used in traditional folk medicine for the treatment of malaria [4], and anti-shigellosis cytotoxic potency [5]. Methanolic extracts of different parts such as leaves, stem, and roots of D. erecta exhibited antifungal properties against Aspergillus flavus, Alternaria sp., Penicillium sp., Rhizopus sp., and Trichoderma sp., [6]. The ethyl acetate extract of leaves reportedly exhibited significant antiplasmodial activity against the chloroquine-sensitive and chloroquine-resistant strains of Plasmodium falciparum [7]. Fruits and stems of $D$. repens exhibited antifungal and antibacterial properties, cytotoxic, and larvicidal to Culex quinquefasciatus [8-10]. Leaves of D. repens exhibited antibacterial properties [4], antioxidant [11], and plant growth-inhibiting activity against seedlings of Brassica juncea var. cernua [7]. The ethyl acetate fraction of the methanol extract of the whole plant of $D$. repens showed radical scavenging activity in the 1,1-diphenyl-2-picrylhydrazyl assay [12], antiviral [13], insecticide properties against Aedes aegypti and Attagenus piceus [14], enzyme- inhibitory activity against thrombin [15], and $\alpha$-glucosidase Inhibitory [16].

The pharmacological significance was noted due to the presence of various bioactive compounds. Several bioactive compounds such as $\beta$-sitosterol, naringenin, acteoside, lamiide, sucrose, and raffinose have been identified and isolated from D. repens [13]. Plant of D. repens is reported to produce triterpenoid-type saponins [7], $C$-alkylated flavonoids [15,16], diterpenoids [15], phenylethanoid glycoside acteoside, the iridoid lamiide and the saponin pseudo-ginsenoside-RT ${ }_{1}$ [12], coumarinolignoids [7,14,17], flavonoid and flavonoid glycosides [17], triterpenoids [18], triterpene saponins [19], iridoid glycosides [20], and steroids [21].

Even though many publications have reported the constituents of D. repens, this plant from Indonesia has still limited and never been reported, yet. Plant products have been part of phytomedicines since time immemorial. This can be derived from barks, leaves, flowers, roots, fruits, and seeds. Knowledge of the chemical constituents of plants is desirable because such information will be valuable for the synthesis of complex chemical substances. Therefore, the current study was aimed to carry out the phytochemical screening of $D$. repens grown in Jombang, East Java, Indonesia, as a justification for its use in traditional medicine. The difference in geographical location will affect the presence of secondary metabolites and drives our interest to conduct the phytochemical investigation of fruits of D. repens.

\section{METHODS}

Collection of plant materials

Fruits of sinyo nakal (D. repens) were collected from trees in Kabupaten Jombang, East Java, Indonesia. 


\section{Preparation of sample}

The collected fruits were cut into tiny pieces, cleansed, and oven-dried in below temperature $40^{\circ} \mathrm{C}$ for $1-2$ weeks. The fruits were ground into a powder and stored in sealed containers to avoid contamination and spoilage.

\section{Preparation of extracts}

Five hundred grams of dried powder of $D$. repens fruits were packed in a separate round bottom flask for sample extraction using $n$-hexane and methanol as solvent, respectively. The extraction was conducted by $750 \mathrm{~mL}$ of the solvent for $72 \mathrm{~h}$ or till the solvent in the siphon tube of an extractor become colorless. Saponification was then performed to the $n$-Hexane extract $\mathrm{NaOH} 0.5 \mathrm{~N}$. The saponification process removed fat or oil or lipid in hexane extract and left an insoluble fraction, known as unsaponifiable fraction. Then, the unsaponifiable fraction and methanol extract were concentrated under reduced pressure and the dried extract was kept in the refrigerator at $4^{\circ} \mathrm{C}$ for their future use in phytochemical analysis.

\section{Phytochemical analysis}

The extracts were prepared for analysis of its phenol, tannins, saponins, alkaloids, flavonoids, terpenoids, and steroids content based on the protocols [22].

\section{Test for phenols and tannins}

The crude extract was mixed with $2 \mathrm{~mL}$ of $2 \%$ solution of $\mathrm{FeCl}_{3}$. A bluegreen or black coloration indicated the presence of phenols and tannins.

\section{Test for saponins}

The crude extract was mixed with $5 \mathrm{~mL}$ of distilled water in a test tube, and it was shaken vigorously. The formation of stable foam was taken as an indication of the presence of saponins.

\section{Test for alkaloids}

The extracts of $D$. repens fruit were evaporated to dryness in a boiling water bath. The residues were dissolved in $2 \mathrm{~N}$ hydrochloric acids. The mixture was filtered, and the filtrate was divided into three equal portions. One portion was treated with a few drops of Mayer's reagent, one portion was treated with an equal amount of Dragendorff's reagent, and the third portion was treated with an equal amount of Wagner's reagent, respectively. The appearance of a white precipitate, the orange precipitate, and brown precipitate indicated the presence of respective alkaloids. Meyer's reagent was prepared by measuring $1.3 \mathrm{~g}$ of mercuric chloride on a weighing balance and $5.0 \mathrm{~g}$ of KI (potassium iodide) and dissolving both in distilled water, made up to $100 \mathrm{~mL}$. Wagner's reagent was prepared by measuring $2 \mathrm{~g}$ of iodine and $6 \mathrm{~g}$ of $\mathrm{KI}$ (potassium iodide) on a weighing balance and dissolving both in distilled water and made up to $100 \mathrm{~mL}$. Dragendorff's reagent was prepared by measuring $5.2 \mathrm{~g}$ Bismuth carbonate and $4 \mathrm{~g}$ potassium iodide on a weighing balance and dissolving both in $50 \mathrm{~mL}$ glacial acetic acid and then boiled for a few minutes. After $12 \mathrm{~h}$, precipitated sodium acetate crystals are filtered by sintered glass funnel, $40 \mathrm{~mL}$ filtrate was added $160 \mathrm{~mL}$ ethyl acetate and $1 \mathrm{~mL}$ distilled water, then stored in an amber-colored glass bottle. $10 \mathrm{~mL}$ stock solution was added to $20 \mathrm{~mL}$ acetic acid and dissolving in distilled water to make a final volume of $100 \mathrm{~mL}$.

\section{Test for flavonoids (shinoda test)}

The extract was mixed with few fragments of magnesium ribbon and concentrated $\mathrm{HCl}$ was added dropwise. The pink scarlet color appeared after a few minutes, which indicated the presence of flavonoids.

\section{Test for steroid}

The extract was mixed with $2 \mathrm{~mL}$ of chloroform. Then $2 \mathrm{~mL}$ of each of concentrated $\mathrm{H}_{2} \mathrm{SO}_{4}$ and acetic acid was poured into the mixture. The development of a greenish coloration indicated the presence of steroids.

\section{Test for terpenoids}

The extract was dissolved in $2 \mathrm{~mL}$ of chloroform and evaporated to dryness. To this, $2 \mathrm{~mL}$ of concentrated $\mathrm{H}_{2} \mathrm{SO}_{4}$ was added and heated for about 2 min. A grayish color indicated the presence of terpenoids.

\section{RESULTS AND DISCUSSION}

Qualitative phytochemical screening of fruits of $D$. repens indicated the presence of tannins, saponins, flavonoids, alkaloids, and steroids for methanol extract, but only steroids for unsaponifiable fraction (Table 1). The unsaponifiable fraction was found to be a mixture of hydrocarbons ranging from $\mathrm{C}_{13}-\mathrm{C}_{20}$, fatty acid (palmitic and linoleic acid), squalene (1), and tocopherol (Vitamin E, 2), while from methanol extract has been elucidated as trans-cinnamic acid (3) by NMR includes ${ }^{1} \mathrm{H},{ }^{13} \mathrm{C}, \mathrm{HSQC}$, HMBC, and TOCSY spectrum [23]. The compounds structure of 1,2 , and 3 is illustrated in Fig. 2.

A previous study [13] reported that the unsaponifiable fraction of whole parts of $D$. repens that was collected from Giza, Egypt, contained a mixture of hydrocarbons ranging from $\mathrm{C}_{15}-\mathrm{C}_{27}$. Another report [18] explained that chemical investigation of the dichloromethane extract of the flowers of D. erecta $L$. from the Philippines has led to the isolation of oleanolic acid, a mixture of $\alpha$-amyrin and $\beta$-amyrin in a 3:1 ratio, phytyl fatty acid esters, and triacylglycerols.

Literature studies by Ahmad et al. [14] reported phytochemicals contain in the methanol extract of $D$. repens leaves that were collected around Mysore, India, included tannins, saponins, flavonoids, glycosides, steroids, and terpenoids. Phytochemical profiling of D. repens also revealed the presence of some imperative phytochemicals such as alkaloids, flavonoids, glycosides, phenolics, saponins, steroids, tannins, and terpenoids [1]. Phytochemical screening of the ethanol extract of D. erecta leaves and fruits from Ghana also indicated the presence of tannins, glycosides, saponins, flavonoids, triterpenoids, and sterol in ethanol extract leaves, both unripe and ripe fruit. Besides, unripe fruit also contained alkaloids [24]. The methanol extract of $D$. erecta leaves that were collected from Tamil Nadu, South India, was found to contain sugars, tannins, alkaloids, phenols, flavonoids, saponins, triterpenes, and carboxylic acid. Moreover, the aqueous extract was found to contain tannins, alkaloids, phenols, flavonoids, saponins, catechins, and glycosides [10].

The methanol extract of D. erecta (L) leaves that were collected from CSIR-National Chemical Laboratory Colony, Pune, indicated the presence of secondary metabolites such as glycoside, saponins, sterols, flavonoids, phenols, tannins, alkaloids, carbohydrates, and proteins [25]. The aqueous extract of $D$. erecta fresh leaves was collected from the residential quarters within the University of Nigeria, Nsukka, indicated small quantities (+) of alkaloids, flavonoids, tannins, anthraquinone, and glycosides in the extract, while saponins were moderately present (++), steroids were conspicuously absent [26]. The $70 \%$ aqueous ethanol of $D$. erecta $\mathrm{L}$. leaves was collected from Nigeria indicated the presence of secondary metabolites such as steroidal glycoside, saponins, flavonoids, polyphenols/tannins, alkaloids, and terpenes [27]. The difference in phytochemicals results was presumably due to several factors, such as growing area, environmental stress such as heavy metals or ultraviolet exposure, age of plants, genetic factors, and physical factors such as climate, humidity, temperature, and weather [28].

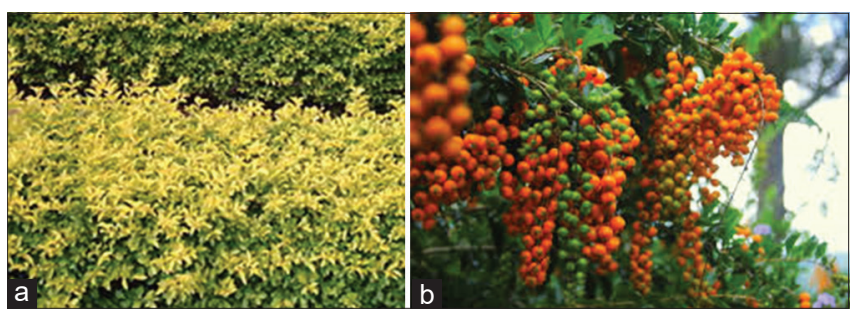

Fig. 1: Morphology of the plant (a) and (b) fruits of Duranta repens $L$. 
Table 1: Phytochemicals screening of D. repens

\begin{tabular}{|c|c|c|c|c|c|c|c|}
\hline \multirow[t]{2}{*}{ Plant } & \multirow[t]{2}{*}{ Extract } & \multicolumn{6}{|c|}{ Secondary metabolites } \\
\hline & & tannins & saponins & flavonoids & alkaloids & steroids & Terpenoids \\
\hline D. repens fruits & $\mathrm{MeOH}$ & + & + & + & + & + & - \\
\hline D. repens leaves [14] & $\mathrm{MeOH}$ & + & + & + & - & + & + \\
\hline \multicolumn{8}{|l|}{ D. erecta $[24]$} \\
\hline Leaves & EtOH & + & + & + & - & - & + \\
\hline Unripe fruits & & + & + & + & + & + & + \\
\hline Ripe fruits & & + & + & + & - & + & + \\
\hline \multirow{2}{*}{ D. erecta leaves [10] } & $\mathrm{MeOH}$ & + & + & + & + & - & + \\
\hline & Water & + & + & + & + & - & - \\
\hline D. erecta leaves [25] & $\mathrm{MeOH}$ & + & + & + & + & + & - \\
\hline D. erecta fresh leaves [26] & Water & + & + & + & + & - & - \\
\hline D. erecta (L) leaves [27] & $70 \%$ aqueous ethanol & + & ++ & + & + & + & + \\
\hline
\end{tabular}

D. repens: Duranta repens, D. erecta: Duranta erecta<smiles>CC(C)=CCC/C(C)=C/CC/C(C)=C/CC/C=C(\C)CC/C=C(\C)CCC=C(C)C</smiles>

(1)<smiles>O=C(O)/C=C/c1ccccc1</smiles><smiles>Cc1c(C)c2c(c(C)c1O)CC[C@@](C)(CCC[C@H](C)CCC[C@H](C)CCCC(C)C)O2</smiles>

Fig. 2: The structures of (1) and (2) from unsaponifiable fraction and (3) from methanol extract of Duranta repens fruits were collected from Jombang, East Java, Indonesia

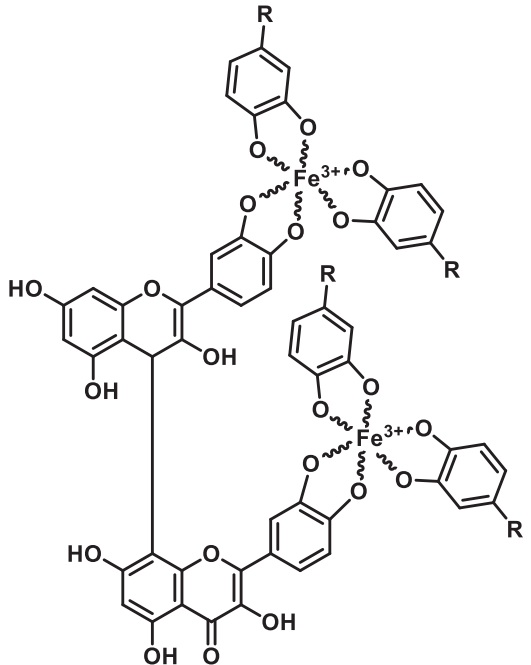

Fig. 3: The proposed tannin complex with $\mathrm{FeCl}_{3}$

In tannin testing, methanol extract showed positive results with the formation of a blackish green color that indicates the formation of complex compounds between tannins and $\mathrm{Fe}^{3+}$ ions, but not detected in unsaponifiable fraction. The blackish-green color has been known to be the complex between $\mathrm{Fe}^{3+}$ and tannins (polyphenols) [29]. The reaction between tannic acid and Fe(III) in carbonate buffer solution forms yellow-green complex while the reaction between tannic acid and Fe(II) in carbonate buffer solution forms magenta complex. The tannin acts as a ligand due to the presence of $\mathrm{O}$ atom, which has a pair of free electrons that can bind covalent coordinates to the $\mathrm{Fe}^{3+}$ as the central ion. Fig. 3 explained that $\mathrm{Fe}^{3+}$ ions bind to three pairs of oxygen donor at 4 ' and $5^{\prime}$ positions from the tannins structure. This position has the lowest energy, thus allowing to form a stable complex.<smiles>O=c1c(O)c(-c2ccc(O)c(O)c2)oc2cc(O)cc(O)c12</smiles>

Fig. 4: The proposed flavonoids reaction with $\mathrm{Mg}$ and $\mathrm{HCl}$

$$
\begin{aligned}
& \mathrm{HgCl}_{2}+2 \mathrm{KI} \rightarrow \mathrm{Hgl}_{2}+2 \mathrm{KCl} \\
& \mathrm{Hgl}_{2}+\mathrm{KI}(\text { excess }) \rightarrow \mathrm{K}_{2}\left[\mathrm{HgI}_{4}\right] \\
& (\text { alkaloid })+\mathrm{K}_{2}\left[\mathrm{HgI}_{4}\right] \rightarrow\left[\text { Alkaloid }^{+}\right]_{2 \mathrm{n}}\left[\mathrm{HgI}_{4}-\right]_{\mathrm{n}} \\
& \text { a } \\
& \mathrm{I}_{2}+\mathrm{KI} \rightarrow \mathrm{KI}_{3} \\
& (\text { alkaloid })+\mathrm{KI}_{3} \rightarrow\left[\text { Alkaloid }^{+}\right]_{\mathrm{n}}\left[\mathrm{I}_{3}\right]_{\mathrm{n}} \\
& \text { b } \\
& \mathrm{Bi}\left(\mathrm{NO}_{3}\right)_{3}+3 \mathrm{KI} \rightarrow \mathrm{Bil}_{3}+3 \mathrm{KNO}_{3} \\
& \left.\mathrm{Bil}{ }_{3}+\mathrm{KI}(\text { excess }) \rightarrow \mathrm{K}^{2} \text { Bil }_{4}\right] \\
& (\text { alkaloid })+\mathrm{K}\left[\mathrm{Bil}{ }_{4}\right] \rightarrow\left[\text { Alkaloid }^{+}\right]_{\mathrm{n}}\left[\mathrm{Bil}_{4}-\right]_{\mathrm{n}}
\end{aligned}
$$

Fig. 5: The proposed alkaloid reaction with Mayer's (a), Wagner's (b), and Dragendorff's (c) reagents

In flavonoids testing, methanol extract showed positive results with the formation of a dark yellow to red solution that indicating the formation of flavylium salts. In contrast, unsaponifiable fraction suggested to no 
flavonoid content. The reaction of flavonoids with metals $\mathrm{Mg}$ and $\mathrm{HCl}$ has been known as the Willstatter and Bate-Smith reactions. Metal Mg that was involved in the reaction acts as a reducing agent which transforms the benzopyrone moiety in the flavonoid structure to red or orange flavylium salts. The reaction refers to Clemmensen reduction. The metal supplies the electrons and the hydrochloric acid supplies the protons to achieve the carbonyl reduction. The proposed flavonoids reaction with $\mathrm{Mg}$ and $\mathrm{HCl}$ is explained in Fig. 4. This result was also confirmed to the reported result of flavonoid contents in D. repens from Pakistan and Egypt [13,16,17].

Alkaloid detecting reagents were solutions of the salts of heavy metals. The most common reagents are Mayer's (potassium iodide-mercuric chloride), Wagner's (iodine-potassium iodide), and Dragendorff's (potassium iodide-bismuth nitrate). In the preparation of Dragendorff's reagents, bismuth nitrate was dissolved in $\mathrm{HCl}$ to prevent the hydrolysis reactions due to bismuth salts were easily hydrolyzed to bismutyl ions $\left(\mathrm{BiO}^{+}\right)$. The reaction mechanism of action has been proposed to occur through coupling of the reagent's heavy metal atom in the reagent with the nitrogen in the alkaloid to form ion pairs. The ion pairs form an insoluble precipitate. The proposed alkaloid reactions with Mayer, Wagner, and Dragendorff reagents afforded precipitations white color complexes ([alkaloids $\left.{ }^{+}\right]_{2 n}\left[\mathrm{HgI}_{4}^{-}\right]_{\mathrm{n}}$ ), light brown ([alkaloids $\left.{ }^{+}\right]_{\mathrm{n}}\left[\mathrm{I}_{3}{ }^{-}\right]_{\mathrm{n}}$ ), and orange ([alkaloids $\left.\left.{ }^{+}\right]_{n}\left[\mathrm{BiI}_{4}^{-}\right]_{n}\right)$, respectively $[30,31]$. The precipitation color could vary from orange-red, yellow-orange, red-black, and pinkpurple depending on the species or genus [32]. The proposed alkaloid reaction with all three reagents is explained in Fig. 5.

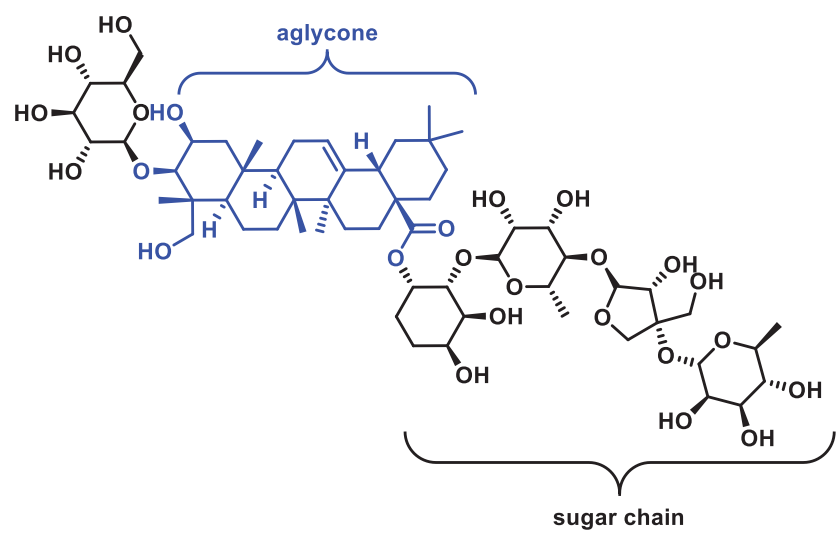

Fig. 6. Structure of Durantanin I, saponin from the leaves of $D$. repens leaves collected from Bangkok, Thailand

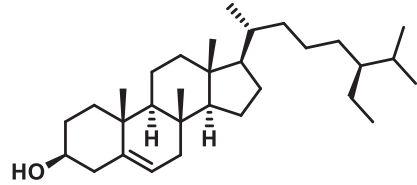

Fig. 8: Chemical structure of $\beta$-sitosterol

D. repens methanol extract also showed positive results on saponin identification. It formed a stable foam for $30 \mathrm{~min}$, but the same result could not be detected in unsaponifiable fraction of $n$-hexane extract. Saponins consist of a polycyclic aglycones attached to one or more sugar side chains. The foaming ability of saponins was caused by the combination of a hydrophobic (fat-soluble) sapogenin and a hydrophilic (water-soluble) sugar part [33]. The previous study has also reported saponin content from $D$. Repens grown in Thailand and Egypt $[7,19]$. Durantanin I (Fig. 6) was the common saponins found in D. repens [17].

Moreover, both samples give a negative result in terpenoids testing, while steroids testing of both samples showed positive results which, as indicated by the formation of a bluish-green solution. Fig. 7 illustrated an example of the reaction of cholesterol with Liebermann-Burchard reagent [34]. The steroid core structure was typically composed of 17 carbon atoms, bonded in four "fused" rings: Three six-member cyclohexane rings (rings A, B, and C) and one five-member cyclopentane ring (the D ring). A steroid from ethanol extract of whole D. repens that was collected in Giza, Egypt, was identified as24-ethylcholest-5-en-3- $\beta$-ol ( $\beta$-sitosterol, 20) (Fig. 8) [13].

The phytochemical screening of $D$. repens plays an important role in pharmaceutical studies, especially to discover some new potential drugs for the treatment of various diseases. Therefore, D. repens extract could be a good source of multi-targeted drugs. The traditional medicine practice was recommended strongly for $D$. repens as well as it is suggested that further work should be carried out to isolate, purify, and characterize the active constituents responsible for the activity of this plant. The additional work is also encouraged to elucidate the mechanism that corresponds to the bioactivity of this extract.

\section{CONCLUSSION}

The methanol extract of sinyo nakal fruits (D. repens L.) was the source of the secondary metabolites ranging from tannins, saponins, alkaloids, flavonoid, and steroids. $n$-Hexane extract was found to be a mixture of hydrocarbons ranging from $\mathrm{C}_{13}-\mathrm{C}_{20}$, fatty acid (palmitic and linoleic acid), squalene, and Vitamin $\mathrm{E}$ while unsaponifiable fraction of $n$-hexane extract was also found to contain steroids.
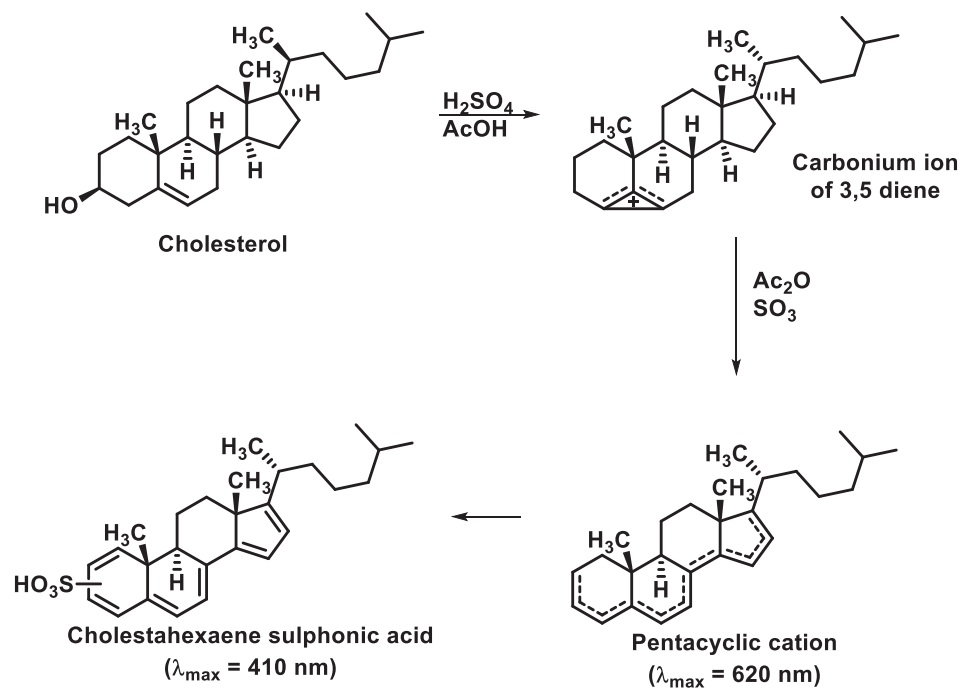

Fig. 7: Reaction scheme for derivatization of cholesterol through Liebermann-Burchard reaction 


\section{AUTHORS' FUNDING}

The authors acknowledge Penelitian Unggulan Lintas Fakultas tahun 2013-2014 with agreement contract No. 243/IT3.41.2/L2/SPK/2013 from LPPM IPB University, Bogor, Indonesia for funding this research.

\section{REFERENCES}

1. Puri AV. Duranta repens linn. (Verbenaceae): A comprehensive review of pharmacognostic, ethnomedicinal, pharmacological, and phytochemical aspects. Asian J Pharm Clin Res 2018;11:91-6.

2. Wiart C. Medicinal Plants of Asia and The Pacific. Boca Raton, US: Taylor and Francis; 2011.

3. Andreu MG, Friedman MH, McKenzie M, Quintana HV, Northrop RJ. Duranta erecta, Golden Dewdrop. Florida, US: University of Florida IFAS Extension; 2010

4. Jayalakshmi B, Raveesha KA, Amruthesh KN. Phytochemical investigations and antibacterial activity of some medicinal plants againts pathogenic bacteria. J Appl Pharm Sci 2011;1:124-8.

5. Nikkon F, Habib MR, Karim MR, Hossain MS, Mosaddik MA, Haque ME. Antishigellosis and cytotoxic potency of crude extracts and isolated constituents from Duranta repens. Mycobiology 2008a;36:173-7.

6. Sharma P, Khandelwal S, Singh T, Vijayvergia R. Phytochemical analysis and antifungal potential of Duranta erecta against some phytopathogenic fungi. Int J Pharm Sci Res 2012;3:2686-9.

7. Hiradate S, Yada H, Ishii T, Nakajima N, Ohnishi-Kameyama M, Sugie $\mathrm{H}$, et al. Three plant growth inhibiting saponins from Duranta repens. Phytochemistry 1999;52:1223-8.

8. Nikkon F, Hasan S, Rahman MH, Hoque MA, Mosaddik MA, Haque ME. Biochemical, hematological and histiphatological effects of Duranta repens stem on rats. Asian J Biochem 2008b;2:366-72.

9. Nikkon F, Saud ZA, Hossain K, Parvin MS, Haque ME. Larvicidal effects of stem and fruits of Duranta repens against the mosquito Culex quinquefasciatus. J Pharm Tech Res 2009;4:1709-13.

10. Serena MM, Balasubraman M, Rajan K, Gerald IA. Evaluation of the larvicidal activity of the leaf extracts of Duranta erecta Linn. (Verbenaceae) on the larvae of Culex quinquefascitatus (Say) (Culicidae). J Biopestic 2010;3:582-5.

11. Adu F, Gbedema SY, Brown P, Annan K, Boamah VE. Antibacterial and free radical scavenging activity of Duranta plumieri Linn. J Pharm Sci Res 2011;2:282-7.

12. Shahat AA, Nazif NM, Abou-Setta LM, Ibrahim NA, Cos P, Miert SV, et al. Phytochemical investigation and antioxidant activity of Duranta repens. Phytother Res 2005;19:1071-3.

13. Abou-Setta LM, Nazif NM, Shahat AA. Phytochemical investigation and antiviral activity of Duranta repens. J Appl Sci Res 2007;3:1426-33.

14. Ahmad N, Zeb F, Ahmad I, Wang F. Repenins A-D, four new antioxidative coumarinolignoids from Duranta repens Linn. Bioorg Med Chem Lett 2009;19:3521-4.

15. Anis I, Anis E, Ahmed S, Mustafa G, Malik A, Amtul Z, et al. Thrombin inhibitory constituents from Duranta repens. Helvchim Acta 2001;84:649-55.
16. Iqbal K, Malik A, Mukhtar N, Anis I, Khan SN, Iqbal M. Alphaglucosidase inhibitory constituents from Duranta repens. Chem Pharm Bull (Tokyo) 2004;52:785-9.

17. Ijaz F, Ahmad N, Ahmad I, Haq AU, Wang F. Two new anti-plasmodial flavonoid glycosides from Duranta repens. J Enzym Inhib Med Chem 2010;25:773-8.

18. Vivar JL, Reyes MM, Shen CC, Ragasa CY. Chemical constituents of Duranta erecta L. Flowers. Pharm Lett 2016;8:234-6.

19. Ahmed WS, Mohamed MA, El-Dib RA, Hamed MM. New triterpene saponins from Duranta repens Linn. and their cytotoxic activity. Molecules 2009;14:1952-65.

20. Ijaz F, Haq A, Ahmad I, Ahmad N, Hussain J, Chen S. Antioxidative iridoid glycosides from the sky flower (Duranta repens Linn). J Enzym Inhib Med Chem 2011;26:88-92.

21. Kuo YH, Chen ZS, Lin YL. Chemical components of the leaves of Duranta repens Linn. Chem Pharm Bull 1996;44:429-36.

22. Shaikh JR, Patil MK. Qualitative tests for preliminary phytochemical screening: An overview. Int J Chem Stud 2020;8:603-8.

23. Januar SE, Sugita P, Arifin B. Identification of trans-cinnamic acid in sinyo nakal (Duranta repens) fruits' methanol extract. Int Res J Pure Appl 2015;8:73-80.

24. Donkor S, Larbie C, Komlaga G, Emikpe BO. Phytochemical, antimicrobial, and antioxidant profiles of Duranta erecta L. Parts. Biochem Res Int 2019;2019:8731595.

25. Agawane SB, Gupta VS, Kulkarni MJ, Bhattacharya AK, Koratkar SS, Rao VK. Patho-physiological evaluation of Duranta erecta for the treatment of urolithiasis. J Ayurveda Integr Med 2017;30:1-8.

26. Agwu EJ, Odo EG, Ekeh F, Uwagbae M, Ngwu G, Ehilegbu C. Bioefficacy of Duranta erecta Leaf extract on yellow fever and dengue vector, Aedes aegypti Linn. In Nigeria. J Med Plants Res 2018; $12: 124-32$

27. Johnson E, Udoh A, Etim E, Attih E, Williams I. Phytochemicals studies, proximate and mineral composition of ethanol leaf extract of Duranta repens Linn (Verbenaceae). Res J Phytochem 2018;12:1-6.

28. Figueiredo AC, Barroso JG, Pedro LG, Scheffer JJ. Factors affecting secondary metabolite production in plants: Volatile components and essential oils. Flavour Fragr J 2008;23:213-26.

29. Fu Z, Chen R. Study of complexes of tannic acid with Fe (III) and Fe (II). J Anal Methods Chem 2019;2019:3894571.

30. Katavic PL. Chemical Investigations of the Alkaloids from the Plants of the Family Elaeocarpaceae. Queensland, Australia: Griffith university; 2006. p. 59-60.

31. Tiwari PK, Kaur M, Kaur H. Phytochemical screening and extraction: A review. Int Pharm Sci 2011;1:98-106.

32. Coe FG, Anderson GJ. Screening of medicinal plants used by the Garifuna of Eastern Nicaragua for bioactive compounds. J Ethnopharmacol 1996;53:29-50.

33. Moghimipour E, Handali S. Saponin: Properties, methods of evaluation and applications. Ann Res Rev Biol 2015;5:207-20.

34. Adu JK, Amengor CD, Kabiri N, Orman E, Patamia SA, Okrah BK. Validation of a simple and robust liebermann-burchard colorimetric method for the assay of cholesterol in selected milk products in Ghana. Int J Food Sci 2019;2019:9045938. 